\title{
SUITABILITY OF OSTRICH EGGSHELL FOR RADIOCARBON DATING
}

\author{
John C Vogel • Ebbie Visser • Annemarie Fuls \\ Quaternary Dating Research Unit, Council for Scientific and Industrial Research, P.O.Box 395, Pretoria 0001, South Africa. \\ Email: jvogel@csir.co.za.
}

\begin{abstract}
Ostrich eggshell from archaeological sites remains largely free of more recent carbon contamination and as such is suitable material for radiocarbon dating. The carbonate fraction of the shell does, however, display an initial deficit in ${ }^{14} \mathrm{C}$, which causes the ages to appear $180 \pm 120 \mathrm{yr}$ too old.
\end{abstract}

\section{INTRODUCTION}

Ostrich eggshell fragments are a frequent occurrence on archaeological sites throughout semi-arid and arid Africa. Often they represent the only datable material on such sites and the question arises as to the reliability of radiocarbon dates on this material. Freundlich et al. (1988) reported approximate correspondence with charcoal dates for mid-Holocene sites, provided a correction for isotope fractionation is applied. Considerable discrepancies still remained, however, and a closer evaluation is called for. In 1978 we mentioned in passing that ostrich eggshell appears to produce dates that are about 200 years too old (Horowitz et al. 1978). Data substantiating this claim are presented here. The results are all automatically adjusted for isotope fractionation with the aid of the ${ }^{13} \mathrm{C}$ content of the carbon analyzed.

\section{Contamination}

In certain respects, ostrich eggshell appears to act as a closed system. This is in marked contrast to material such as bone or sea shells, the carbonate fraction of which is known to be subject to postdepositional diagenesis and frequently apt to produce apparent ages that are too young. As an example of the low tendency for contamination with modern carbon, we cite some results for the carbonate fraction of eggshell fragments from archaeological sites in Table 1.

The three samples in the upper part of the table were collected from exposed land surfaces. The first two give acceptable ages for the associated artifacts, while the third was together with Bronze Age material, showing that the eggshell had been lying on the surface since long before the people of the Bronze Age occupied the site. These three samples have thus picked up less than $1.5 \%$ modern carbon, despite having been exposed to an average annual rainfall in excess of $200 \mathrm{~mm}$ over the past millennia. The bottom four samples in the table are examples of ostrich eggshell from archaeological excavations that show no measurable ${ }^{14} \mathrm{C}$, again indicating that no contamination with modern carbon has taken place.

Further evidence that ostrich eggshell represents a closed system is the success achieved with amino acid epimarization dating of the protein fraction of the shell from several sites in South Africa (Miller et al. 1992). This again is in contrast to the unsatisfactory behavior of bone and sea shell.

\section{Comparison With Charcoal And Bone}

In the light of these indicators that the eggshell remains relatively free of more recent contamination, one may expect it to provide suitable material for ${ }^{14} \mathrm{C}$ dating. To further test this assumption, we analyzed pairs of ostrich eggshell and charcoal from the same level at a number of archaeological sites. The results are listed in Table 2.

In all cases (except one), the eggshell carbonate gives an older age than the charcoal. The first seven pairs in the list appeared to constitute a reasonably consistent set with a weighted average difference 
Table 1 Radiocarbon dates for old archaeological samples showing lack of modern carbon contamination

\begin{tabular}{|c|c|c|c|c|}
\hline $\begin{array}{l}\text { Site and } \\
\text { association }\end{array}$ & Region & $\begin{array}{l}\text { Sample nr } \\
\text { (Pta-) }\end{array}$ & $\begin{array}{c}{ }^{14} \mathrm{C} \text { content } \\
(\mathrm{pMC})\end{array}$ & Age (BP) \\
\hline $\begin{array}{l}\text { T'boop, Calvinia distr. } \\
\text { Middle Stone Age }\end{array}$ & NW Cape & 5290 & $0.98 \pm 0.08$ & $37,400 \pm 630$ \\
\hline $\begin{array}{l}\text { Quseima } \\
\text { Upper Palaeolithic }\end{array}$ & NE Sinai & 2946 & $1.81 \pm 0.18$ & $32,470 \pm 780$ \\
\hline $\begin{array}{l}\text { Coastal plain } \\
\text { Early Bronze Age (!) }\end{array}$ & NE Sinai & 2941 & $1.45 \pm 0.18$ & $34,300 \pm 1000$ \\
\hline $\begin{array}{l}\text { Apollo 11, La F } \\
\quad \text { Middle Stone Age }\end{array}$ & S Namib desert & 1415 & $-0.04 \pm 0.13$ & $>48,400$ \\
\hline $\begin{array}{l}\text { Apollo 11, La G } \\
\text { Middle Stone Age }\end{array}$ & S Namib desert & 505 & $-0.02 \pm 0.09$ & $>50,500$ \\
\hline $\begin{array}{l}\text { Avdat, Le 5-7 } \\
\text { Mousterian }\end{array}$ & Negev desert & 543 & $0.18 \pm 0.12$ & $>44,000$ \\
\hline $\begin{array}{l}\text { Avdat, Le 9-11 } \\
\text { Mousterian }\end{array}$ & Negev desert & 546 & $0.00 \pm 0.08$ & $>51,000$ \\
\hline
\end{tabular}

Table 2 Radiocarbon analysis of assumed contemporary pairs of ostrich eggshell (oes) carbonate and charcoal from Later Stone Age sites in the northern Cape, South Africa

\begin{tabular}{|c|c|c|c|c|c|c|c|}
\hline $\begin{array}{l}\text { Site and } \\
\text { position }\end{array}$ & $\begin{array}{l}\text { Sample nr } \\
\text { (Pta-) }\end{array}$ & Material & $\begin{array}{l}\delta^{13} \mathrm{C} \\
(\% o)\end{array}$ & $\begin{array}{l}{ }^{14} \mathrm{C} \text { content } \\
(\mathrm{pMC})^{*}\end{array}$ & $\begin{array}{c}{ }^{14} \mathrm{C} \text { deficit } \\
(\%)\end{array}$ & $\begin{array}{l}\text { Age } \\
(\mathrm{BP})\end{array}$ & $\begin{array}{c}\text { Age diff. } \\
(\mathrm{yr})\end{array}$ \\
\hline $\begin{array}{l}\text { Arbeidsvreug } \\
\quad(20 \mathrm{~cm})\end{array}$ & $\begin{array}{l}4851 \\
4905\end{array}$ & $\begin{array}{l}\text { Charcoal } \\
\text { oes,carb. }\end{array}$ & $\begin{array}{r}-23.2 \\
-7.1\end{array}$ & $\begin{array}{l}98.1 \pm 0.6 \\
93.8 \pm 0.6\end{array}$ & $4.4 \pm 0.8$ & $\begin{array}{l}157 \pm 46 \\
519 \pm 47\end{array}$ & $362 \pm 66$ \\
\hline $\begin{array}{l}\text { Meerlust } 1 \\
(28 \mathrm{~cm})\end{array}$ & $\begin{array}{l}4507 \\
4508\end{array}$ & $\begin{array}{l}\text { Charcoal } \\
\text { oes,carb. }\end{array}$ & $\begin{array}{r}-24.5 \\
-8.5\end{array}$ & $\begin{array}{l}97.7 \pm 0.5 \\
96.5 \pm 0.5\end{array}$ & $1.2 \pm 0.7$ & $\begin{array}{l}184 \pm 40 \\
285 \pm 35\end{array}$ & $101 \pm 53$ \\
\hline $\begin{array}{l}\text { T'kokobos } \\
\text { surface }\end{array}$ & $\begin{array}{l}4860 \\
4844\end{array}$ & $\begin{array}{l}\text { Potsherd } \\
\text { oes,carb. }\end{array}$ & $\begin{array}{r}-21.2 \\
-8.2\end{array}$ & $\begin{array}{l}94.7 \pm 0.4 \\
94.5 \pm 0.6\end{array}$ & $0.2 \pm 0.7$ & $\begin{array}{l}436 \pm 35 \\
454 \pm 47\end{array}$ & $18 \pm 57$ \\
\hline $\begin{array}{l}\text { Prospector } \\
\text { Cave, La } 3\end{array}$ & $\begin{array}{l}4174 \\
4160\end{array}$ & $\begin{array}{l}\text { Charcoal } \\
\text { oes,carb. }\end{array}$ & $\begin{array}{r}-22.2 \\
-4.2\end{array}$ & $\begin{array}{l}93.1 \pm 0.6 \\
92.5 \pm 0.6\end{array}$ & $0.7 \pm 0.8$ & $\begin{array}{l}573 \pm 48 \\
628 \pm 47\end{array}$ & $55 \pm 67$ \\
\hline $\begin{array}{c}\text { Limerock } 1 \\
\text { spit II }\end{array}$ & $\begin{array}{l}4450 \\
4432\end{array}$ & $\begin{array}{l}\text { Charcoal } \\
\text { oes,carb. }\end{array}$ & $\begin{array}{r}-23.4 \\
-6.7\end{array}$ & $\begin{array}{l}90.4 \pm 0.5 \\
90.2 \pm 0.6\end{array}$ & $0.3 \pm 0.8$ & $\begin{array}{l}809 \pm 48 \\
833 \pm 50\end{array}$ & $24 \pm 69$ \\
\hline $\begin{array}{c}\text { Limerock } 1 \\
\text { spit III }\end{array}$ & $\begin{array}{l}1621 \\
4452\end{array}$ & $\begin{array}{l}\text { Charcoal } \\
\text { oes,carb. }\end{array}$ & $\begin{array}{r}-22.7 \\
-7.4\end{array}$ & $\begin{array}{l}81.3 \pm 0.5 \\
78.9 \pm 0.6\end{array}$ & $3.0 \pm 0.8$ & $\begin{array}{l}1661 \pm 51 \\
1903 \pm 55\end{array}$ & $242 \pm 75$ \\
\hline $\begin{array}{c}\text { Limerock } 2 \\
\text { spit IV }\end{array}$ & $\begin{array}{l}2095 \\
4502\end{array}$ & $\begin{array}{l}\text { Charcoal } \\
\text { oes,carb. }\end{array}$ & $\begin{array}{r}-23.5 \\
-7.6 \\
\end{array}$ & $\begin{array}{l}80.8 \pm 0.4 \\
79.5 \pm 0.5\end{array}$ & $1.6 \pm 0.7$ & $\begin{array}{l}1716 \pm 40 \\
1844 \pm 50\end{array}$ & $129 \pm 64$ \\
\hline & & $\begin{array}{l}\text { Weighted } \\
\text { Standard }\end{array}$ & $\begin{array}{l}\text { erage: } \\
\text { viation: }\end{array}$ & & $\begin{array}{l}1.58 \\
1.54\end{array}$ & & $\begin{array}{l}125 \\
125\end{array}$ \\
\hline $\begin{array}{c}\text { Limerock } 2 \\
\text { spit V }\end{array}$ & $\begin{array}{l}1759 \\
4435\end{array}$ & $\begin{array}{l}\text { Charcoal } \\
\text { oes,carb. }\end{array}$ & $\begin{array}{r}-23.5 \\
-7.2\end{array}$ & $\begin{array}{l}83.7 \pm 0.5 \\
78.6 \pm 0.5\end{array}$ & $6.2 \pm 0.7$ & $\begin{array}{l}1430 \pm 50 \\
1940 \pm 50\end{array}$ & $510 \pm 70$ \\
\hline $\begin{array}{l}\text { Klein Witkrans } \\
\text { spit } 3\end{array}$ & $\begin{array}{l}2447 \\
4499\end{array}$ & $\begin{array}{l}\text { Charcoal } \\
\text { oes,carb. }\end{array}$ & $\begin{array}{r}-24.6 \\
-8.3\end{array}$ & $\begin{array}{l}83.1 \pm 0.4 \\
73.0 \pm 0.4\end{array}$ & $12.2 \pm 0.6$ & $\begin{array}{l}1490 \pm 40 \\
2530 \pm 45\end{array}$ & $1045 \pm 60$ \\
\hline $\begin{array}{l}\text { Klein Witkrans } \\
\text { spit } 4\end{array}$ & $\begin{array}{l}4453 \\
4444\end{array}$ & $\begin{array}{l}\text { Charcoal } \\
\text { oes,carb. }\end{array}$ & $\begin{array}{r}-24.0 \\
-7.2\end{array}$ & $\begin{array}{l}77.2 \pm 0.4 \\
77.5 \pm 0.5\end{array}$ & $-0.5 \pm 0.7$ & $\begin{array}{l}2080 \pm 45 \\
2040 \pm 50\end{array}$ & $-41 \pm 67$ \\
\hline $\begin{array}{l}\text { Klein Witkrans } \\
\text { spit } 5\end{array}$ & $\begin{array}{l}3418 \\
4497\end{array}$ & $\begin{array}{l}\text { Charcoal } \\
\text { oes,carb. }\end{array}$ & $\begin{array}{r}-24.4 \\
-8.5\end{array}$ & $\begin{array}{l}79.6 \pm 0.5 \\
60.1 \pm 0.5\end{array}$ & $24.6 \pm 0.7$ & $\begin{array}{l}1830 \pm 50 \\
4100 \pm 60\end{array}$ & $2264 \pm 78$ \\
\hline $\begin{array}{l}\text { Bokvasmaak } \\
\text { near surface }\end{array}$ & $\begin{array}{l}4873 \\
4877\end{array}$ & $\begin{array}{l}\text { Potsherd } \\
\text { oes,carb. }\end{array}$ & $\begin{array}{r}-20.6 \\
-6.3\end{array}$ & $\begin{array}{l}98.0 \pm 0.8 \\
81.7 \pm 0.4\end{array}$ & $16.6 \pm 0.9$ & $\begin{array}{r}160 \pm 70 \\
1620 \pm 35\end{array}$ & $1461 \pm 78$ \\
\hline
\end{tabular}


of 125 years and a standard deviation for a single measurement of 125 years. The next five pairs, however, showed unusually large differences. Especially the eggshell samples from the Klein Witkrans excavation are stratigraphically inconsistent and cannot be accepted. There obviously was churning of the deposit (Pta-4453) and incorporation of older eggshell fragments into the layers. The large discrepancy between the age of the grass temper in the potsherd and the eggshell from the surface collection at Bokvasmaak, the last entry in the table, can also only be interpreted as that the samples are not of the same age.

\section{Modern Eggshell}

These last results show that the approach cannot be used to gain a reliable estimate of any discrepancy in the ages obtained from ostrich eggshell because absolute contemporaneity of such sample pairs from archaeological deposits cannot be guaranteed. A more direct approach would be to analyze modern ostrich eggs of which the date of laying is known. It is necessary to know exactly when the eggs were laid because the elevated ${ }^{14} \mathrm{C}$ content of the environment caused by nuclear weapon tests in the atmosphere has been changing rapidly on an annual basis since 1954 . We, however, have a detailed record of these changes over the years and can accurately predict the ${ }^{14} \mathrm{C}$ level of vegetation for any given season.

For the current purpose, we obtained four ostrich eggshells of which the date of laying is known. With these we analyzed the ${ }^{14} \mathrm{C}$ content of both the inorganic calcium carbonate and the organic protein fractions. The results are listed in Table 3. For one sample we also analyzed the organic contents of the egg-a mixture of the egg white and yolk. Also given is the ${ }^{14} \mathrm{C}$ content of the carbon dioxide of the atmosphere in the month in which the eggs were laid. This closely reflects the ${ }^{14} \mathrm{C}$ content of the growing plants that the birds were eating. In all cases, the protein fraction of the eggs corresponds to that of the vegetation-the average difference being $0.06 \%$, which would reflect an age difference of only 5 years. The standard deviation of a single measurement of \pm 45 years shows that the fluctuations are not greater than the uncertainty of the measurements.

The ${ }^{14} \mathrm{C}$ content of the carbonate fractions are, however, consistently lower than that of the protein and of the environment. In the last two columns of Table 3, the relative deficit of the carbonate fraction with respect to the atmospheric value and the organic fraction are listed. The averages of the deficit are $2.36 \%$ and $2.1 \%$, which corresponds to an age difference of 190 and 170 years, respectively. The standard deviation of a single measurement becomes \pm 115 years. These results are not dissimilar to the average values obtained for the first seven comparative pairs in Table 2.

There seems to be only one explanation of this deficit of ${ }^{14} \mathrm{C}$ in the carbonate of the eggshell, namely that it is caused by the large intake of fossil lime during the laying period. Hens lay an egg every other day over a period of a month or more (McLachlan and Liversidge 1970). An average ostrich eggshell weighs some $280 \mathrm{~g}$, which means that the hen must consume about $140 \mathrm{~g}$ of limestone or calcrete per day to acquire the necessary amount of calcium. This amount of fossil lime apparently suffices to dilute the ${ }^{14} \mathrm{C}$ content in the body fluid from which the calcium carbonate of the eggshell is precipitated by some $2.2 \%$. The result is that it shows an apparent initial age of 180 years. If this explanation is correct, a considerable variability is to be expected depending on the ${ }^{14} \mathrm{C}$ content of the lime consumed and the degree of isotopic exchange with metabolic carbon dioxide in the blood of the hen. The relatively large standard deviation of an individual measurement of \pm 115 years is thus not surprising. 


\section{RESULTS FOR RECENT ARCHAEOLOGICAL SITES}

The fact that ostrich eggshell shows an apparent initial age of some 180 years is further born out in the results we have obtained for recent archaeological sites in the northern and north-western Cape, South Africa (Figure 1): Of the 44 charcoal and bone samples with a ${ }^{14} \mathrm{C}$ content of between $93 \mathrm{pMC}$ and 99 pMC (corresponding to calibrated dates of between AD 1420 and AD 1900), 24 fall in the range $96.5 \mathrm{pMC}$ to $99.0 \mathrm{pMC}$ ( $\mathrm{AD} 1660$ to $\mathrm{AD} 1900$ ). In contrast, only one of the 27 ostrich eggshell samples in this range has a higher ${ }^{14} \mathrm{C}$ content than $96.5 \mathrm{pMC}$, i.e. appears to be younger than $\mathrm{AD}$ 1660. If, on the other hand, a correction of $2.2 \%$ is made for the eggshell, the distribution of dates becomes the same as for the charcoal.

Table 3 Radiocarbon analysis of organic and inorganic fractions of modern ostrich eggshell

\begin{tabular}{|c|c|c|c|c|c|c|c|c|}
\hline \multirow[b]{2}{*}{ Site and date } & \multirow{2}{*}{$\begin{array}{l}\text { Sample nr } \\
\quad \text { (Pta-) }\end{array}$} & \multirow[b]{2}{*}{ Material } & \multirow{2}{*}{$\begin{array}{l}\delta^{13} \mathrm{C} \\
(\% \circ)\end{array}$} & \multirow{2}{*}{$\begin{array}{c}{ }^{14} \mathrm{C} \text { content } \\
(\mathrm{pMC})\end{array}$} & \multirow{2}{*}{$\begin{array}{l}\text { Atm. } \\
\text { (pMC) }\end{array}$} & \multicolumn{3}{|c|}{ Relative difference (\%) } \\
\hline & & & & & & atm-org & atm-carb & org-carb \\
\hline \multirow{2}{*}{$\begin{array}{c}\text { Groblershoop } \\
\text { Sept. } 1970\end{array}$} & 4713 & Organics & -18.4 & $153.2 \pm 0.6$ & 154.0 & $+0.52 \pm 0.44$ & & $2.28 \pm 0.51$ \\
\hline & 1588 & Carbonate & -2.5 & $149.7 \pm 0.5$ & 154.0 & & $+2.79 \pm 0.38$ & \\
\hline \multirow{2}{*}{$\begin{array}{r}\text { Oudshoorn } \\
\text { Jan. } 1977\end{array}$} & 4692 & Organics & -17.0 & $136.2 \pm 0.6$ & 136.4 & $+0.15 \pm 0.46$ & & $3.96 \pm 0.68$ \\
\hline & 1977 & Carbonate & -3.6 & $130.8 \pm 0.7$ & 136.4 & & $+4.11 \pm 0.53$ & \\
\hline \multirow{2}{*}{$\begin{array}{c}\text { Monica-Oos } \\
\text { July } 1987\end{array}$} & 4871 & Organics & -22.5 & $120.2 \pm 0.7$ & 119.4 & $-0.66 \pm 0.61$ & & $2.79 \pm 0.72$ \\
\hline & 4862 & Carbonate & -8.8 & $116.4 \pm 0.5$ & 119.4 & & $+2.18 \pm 0.45$ & \\
\hline \multirow{6}{*}{$\begin{array}{c}\text { Monica-Oos } \\
\text { July } 1988\end{array}$} & 4865 & White \& yolk & -25.3 & $119.1 \pm 0.6$ & 118.4 & $-0.60 \pm 0.53$ & & $1.26 \pm 0.71$ \\
\hline & 4930 & Organics & -21.0 & $117.9 \pm 0.6$ & 118.4 & $+0.46 \pm 0.53$ & & $0.20 \pm 0.66$ \\
\hline & 4899 & Carbonate & -9.9 & $117.6 \pm 0.5$ & 118.4 & & $+0.67 \pm 0.45$ & \\
\hline & & & & & $0.06 \pm 0.23$ & $2.36 \pm 0.22$ & $2.10 \pm 0.29$ \\
\hline & & & \multirow{2}{*}{\multicolumn{3}{|c|}{$\begin{array}{l}\text { Average difference in years: } \\
\text { Standard deviation in years: }\end{array}$}} & 5 & 190 & 170 \\
\hline & & & & & & 45 & 115 & 115 \\
\hline
\end{tabular}

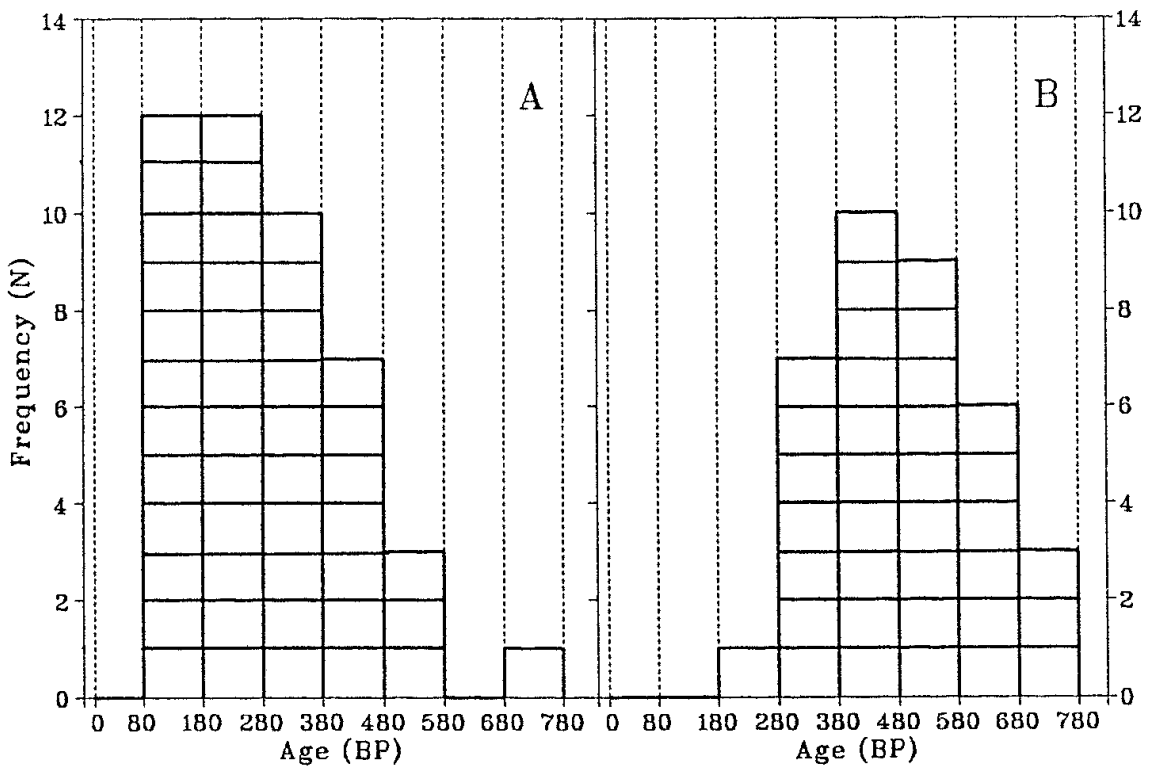

Figure 1 Histograms of uncalibrated ${ }^{14} \mathrm{C}$ ages for samples mainly collected from the surface or nearsurface of open archaeological sites in the northern and northwestern Cape, South Africa. A:Mainly charcoal and some bone samples. B: Ostrich eggshell samples. If 180 years is subtracted from the eggshell ages, the two histograms overlap satisfactorily. 
One further finding needs to be presented here: At a Late Stone Age site on the farm Biesjes Poort in the Northern Cape Province, Peter Beaumont managed to collect some $400 \mathrm{~g}$ of ostrich eggshell fragments from the surface. This sample contained enough organic matter for analysis so that we could compare the radiocarbon content of the organic carbon with that of the carbonate fraction. The results are as follows:

$$
\begin{array}{lllc}
\text { Biesjes Poort } & \text { Pta-4772 } & \text { Organic fraction } & 1390 \pm 70 \mathrm{BP} \\
\text { Site 2, Surface } & \text { Pta-4764 } & \begin{array}{l}
\text { Carbonate fraction } \\
\text { Difference }
\end{array} & \frac{2050 \pm 50 \mathrm{BP}}{660 \pm 86 \mathrm{yr}}
\end{array}
$$

Our explanation for this large difference in the ${ }^{14} \mathrm{C}$ dates is that the shell fragments did not have a uniform age, but derive from a wide range of different ages. Since the protein in this shell gradually decays, the older fragments contain less organic carbon than the younger ones, and the date for the organic fraction is consequently biased towards the youngest date. The carbonate fraction, on the other hand, gives a more representative average date for the sample. The modern ostrich eggshell we have analyzed contains between $0.6 \%$ and $1.0 \%$ organic carbon, while the Biesjes Poort sample had only $0.17 \%$. This shows that most of the protein in the shell has already been lost, and if, for instance, half the sample is 3000 years old and the rest is 1000 years old, giving an average (carbonate) age of 2000 years, it is clear that the organic fraction would date to a figure much closer to 1000 years. This problem of the admixture of older material is also evident in the results listed in the lower part of Table 2 .

\section{CONCLUSION}

With regard to the suitability of ostrich eggshell as a material for ${ }^{14} \mathrm{C}$ dating we may in conclusion summarize as follows:

1. Ostrich eggshell does not seem to be prone to contamination, albeit by recrystallization or precipitation of additional secondary calcium carbonate. As such it is more reliable than bone as a dating material.

2. The carbonate fraction of the eggshell does, however, display an initial deficit of $2.2 \%$ in ${ }^{14} \mathrm{C}$ caused by the large intake of fossil limestone during egg laying which, on average, results in the derived ages to appear some 180 years too old. Due to the nature of the effect such ages will always have an uncertainty of about \pm 120 years.

\section{ACKNOWLEDGMENTS}

We are grateful to Peter Beaumont for supplying us with most of the comparative samples for this analysis.

\section{RERERENCES}

Freundlich JC, Kuper R, Breunig P, Bertram H-G. 1988. Radiocarbon dating of ostrich eggshells. Radiocarbon 31(3):1030-4.

Horowitz A, Sampson CG, Scott L, Vogel JC. 1978. Analysis of the Voigtspost site, O.F.S. South African Archaeological Bulletin 33:152-9.

McLachlan GR, Liversidge R. 1970. Roberts Birds of South Africa. 3rd edition. Cape Town: Trustees of the
Bird Book Fund.

Miller GH, Beaumont PB, Jull AJT, Johnson B. 1992. Pleistocene geochronology and palaeothermometry from protein diagenesis in ostrich eggshells: implications for the evolution of modern humans. Philosophical Transactions of the Royal Society, London B337: 98-102. 